\title{
THE IMPACT OF ORGANIZATIONAL LEARNING ON COMPETITIVE ADVANTAGE IN TURKEY
}

*Seyit EROGLU (Orchid ID: 0000-0002-6771-0192)

*Yonca GUROL (Orchid ID: 0000-0002-0618-5750)

*Ylldı Technical University

\begin{abstract}
Competition continues to increase its impact on the lifetimes of companies. When companies struggle with this pressure, they should consider the learning process. Companies that use organizational learning in the right way aim to survive longer and be successful compared to their rivals thanks to the competitive advantage they gain. The main purpose of this study is to reveal the effect of organizational learning on competitive advantage. While examining this effect, the study deals with four sub-dimensions of organizational learning that are managerial commitment, systems perspective, openness and experimentation, knowledge transfer and integration, according to the classification made by Jerez-Gomez et al (2005). The competitive advantage variable is also examined through the scale developed by Sigalas et al (2013). In this respect, a questionnaire is applied to 388 employees and managers from 319 companies. The collected data are firstly analyzed for reliability and validity, and then VIF, R2, $f 2$, and Q2 values are checked. Afterward, for the structural equation modeling, the partial least squares method (PLS-SEM) is applied to the research through the SmartPLS program. According to the results of the study, organizational learning significantly and positively affects competitive advantage with all its subdimensions. These results are in alignment with the studies in the literature review. In the conclusion part, there are suggestions for both the business world and academia.
\end{abstract}

Keywords: Organizational learning, competitive advantage, strategic management

\section{INTRODUCTION}

Peter Senge (1990) quotes a study in his book and states that Fortune 500 companies have a life expectancy of fewer than 40 years, stating that organizational learning is crucial for companies' survival. It is generally accepted that competition is one of the most important factors affecting the life span of companies. A recent study predicts that the average seniority of S\&P 500 companies, which was between 30 and 35 years in the 1970s, would be between 15 and 20 years in the 2020s (Innosight, 2021). This shows that the increasing pressure brought by competition and the environment is an issue that companies must deal with. Whether organizations consciously manage learning is a separate issue, but learning is an indispensable element for survival (Kim, 1993).

Competition requires an analysis of the environment, rapid adaptation of the entire structure, and a strategic approach to learning for companies. First of all, organizational learning is one of the essential factors to compete globally (Hamel and Prahalad, 1990). To be superior in this competition, a company must learn faster than its competitors at all levels, and a company must be ready for this adaptation with all its structure and activities (Senge, 1990). In addition, organizations need to understand their environment. To do this, they collect outside samples and conduct market research. They can make trend analyses against external influences, use media content analysis and perform econometric modeling. They must do this before resources are exhausted, competitors enter the market, and the environment becomes difficult for them (Daft and Weick, 1984). Similarly, the acquisition and creation of knowledge, along with its transfer and integration within the organization, is considered one of the key strategic resources (Grant, 1996).

As a result of organizational learning, companies can both improve their existing processes and expand the solutions they offer to their customers by operating in different areas. With the competitive advantage obtained in this way, it can achieve better positioning in the market than its competitors by high market share or niche solutions. Other companies will not remain silent against their successful competitors, and competition will encourage them to become better than their current situation. Thus, they will also gain

${ }^{1}$ This paper was produced from the doctoral dissertation conducted by the correspondent author under the supervision of the second author. 
material and moral returns (Lim, 2010). Companies that are still standing and able to maintain their position despite all these efforts of their competitors have a competitive advantage (Porter, 1985). Companies start to learn when competition begins and continues. Those who gain sustainable competitive advantage will have come a long way in organizational learning (Simon, 1991). All these perspectives show us that organizational learning is closely related to the concept of competitive advantage.

\section{LITERATURE REVIEW}

\section{Organizational Learning}

Organizational learning has found its place in academia as a field of study that increases its importance over time with the influence of the environment and competition. It has sometimes been examined in psychological approaches (Daft and Weick, 1984), and sometimes it has been discussed within the scope of Organization Theory (Senge, 1990). In the following years, it has been discussed from strategic management and competitive advantage perspectives by academic circles (Grant, 1996). As a result of the studies, it is revealed that organizational learning is a fundamental element in order to compete in global markets (Hamel and Prahalad, 1990).

The concept of learning can be defined as the development of an individual's capacity to take effective actions (Kim, 1993). In terms of organizations, learning starts from the individual (Senge, 1990). However, compared to individual learning, organizational learning is a more complex phenomenon than just adding together individual learning of its members (Argyris and Schön, 1978; Hedberg, 1981; Kim, 1993).

Learning in organizations occurs as single-loop learning after errors are found and then corrected. Once existing goals, values, plans, and rules are questioned, double-loop learning is achieved (Argyris and Schön, 1978). Double-loop learning will enable organizations to replace inadequate norms with new priorities. In this respect, learning will take place by transforming new information into different reproducible behaviors (Argyris and Schön, 1978).

According to another view, organizational learning is achieved by bringing together individual actions in shared mental models (Kim, 1993). While these individual actions turn into organizational actions over time, they begin to receive some environmental reactions. The cycle is completed when these reactions affect individual reactions within the organization (March and Olsen, 1975).

The importance of acquiring and transferring knowledge has also found its place in academia. Organizational learning begins with the acquisition of knowledge by individuals, continues with the transformation and transfer of knowledge, and is completed by placing it in the organizational culture (Hedberg, 1981). The creation and distribution of knowledge constantly create internal changes in the organization, and in this case, reflections occur at the cognitive and behavioral levels. These changes are regular developments that must be constantly maintained (Fiol and Lyles, 1985).

In this respect, organizational learning can be defined as the creation, acquisition, dissemination, and integration of knowledge while modifying its behaviors and reflecting new cognitive behaviors (JerezGomez, Céspedes-Lorente \& Valle-Cabrera, 2005). Organizational learning should be supported by management (Williams, 2001). A collective consciousness should be created by transferring it to the members of the organization correctly (Senge, 1990); otherwise, employees who do not have a common vision will not contribute (Kim, 1993). In the development of organizational knowledge, the transfer and adoption of knowledge manifest itself as a critical element (Nonaka and Takeushi, 1995). As can be seen, organizational learning has attracted the attention of researchers over the years and this important concept has been examined with its different dimensions.

In addition to the results of the studies, the scale developed by Jerez-Gomez et al. (2005) was used in this study, taking into account the complex and multidimensional nature of the concept. The scale in this study was also evaluated empirically in Spanish companies in the chemical sector. There are four sub-dimensions in the scale, which are managerial commitment, systems perspective, openness and experimentation, and knowledge transfer and integration.

\section{Competitive Advantage}

In today's globalizing world, competition among businesses is one of the most important concepts taken into consideration. As a result of this competition, companies firstly try to survive and then strive for gaining 
an advantage in order to reach successful outcomes. Competitive advantage is an important element for the success of the business (Porter, 2015). By promoting different products and services along with improving current activities, companies can gain a competitive advantage. At this point, it is possible to target a high market share or focus on a niche market. As it could be seen, these activities in terms of gaining competitive advantage are the points to carry the companies forward. It is tried to reach the demands of the customers in various ways.

Expecting competitors to remain silent once they realize the competitive advantage of their rivals would be naive. They will immediately analyze the developments and will start to take action in this way. Porter (1985) asserts that sustainable competitive advantage can be mentioned if the business can still survive despite all these actions and counter moves from competitors. Sometimes, a competitive advantage can be obtained because current and future competitors cannot implement the strategy of the company (Barney, 1991). However, in some cases where the activity is started at the same time, there may be situations where the competitive advantage is lost (Barney and Hesterly, 2008).

According to some academics, the benefits of competition are not mentioned enough (Krugman, 1994). A competitive environment drives businesses to think, learn and develop more. As a result, cumulative improvements in products and services occur. In addition, it is thought that competition will contribute to progress when directed towards a common goal within the enterprise and synergies can be achieved with external cooperation. However, competition is sometimes favored by management due to the motivational effects. For individuals, the competition provides access to financial opportunities and intangible factors such as prestige and popularity ( $\mathrm{Lim}, 2010)$. Another highlighted critical point is that competition is beneficial not only when it starts or during the process, but also when it is completed especially in terms of organizational learning (Simon, 1991).

The concept of competitive advantage is a dynamic process that provides superiority to competitors, and this superiority manifests itself with higher returns or potential (Lynch, 2000; Grant, 2008). Generating creative ideas and finding new methods after innovative actions provide a competitive advantage (Porter, 1990). Competitive advantage can be gained by making advantageous sales agreements compared to competitors, or by offering products and services to customers with innovative methods (Eren, 2013). Competitive advantage is achieved in the long run and has continuity, diversity, and excellence (Porter, 1985).

\section{Relationship between Organizational Learning and Competitive Advantage}

Increasing globalization and a competitive environment have increased the transformation necessity for companies. Organizational learning stands out as an important concept in order to manage the transformation. In this regard, there are studies on the effects of organizational learning on competitive advantage and financial performance. While the effect of organizational learning on competitiveness and financial performance was determined in a study involving 195 companies in Spain (Lopez et al., 2005), another study revealed that companies that implement organizational learning properly will compete successfully (Appelbaum and Gallagher, 2000). In a case study conducted for Algeria Telecom, it is determined that all levels of organizational learning have a positive and significant effect on competitive advantage (Hamama and Tayeb, 2020).

The study, which shows that competitive advantage plays a mediating role in the effect of organizational learning and collective human capital on firm performance, covers 237 multinational manufacturing companies operating in Malaysia and shows that sub-dimensions of organizational learning such as the acquisition, distribution and interpretation of information directly affect competitive advantage (Dass and Chelliah, 2021).

In a recent study involving 235 Chinese manufacturers, the mediating role of organizational learning in the competitive advantage of green innovation strategies, which are important in sustainability, is determined (Tu and $\mathrm{Wu}, 2021$ ). There is also a study including 159 manufacturing companies in Spain, which shows that organizational learning, together with organizational memory, provides competitive advantage through organizational innovation and marketing innovation (Camison and Villar-Lopez, 2011). According to the results of the study, which includes a systematic review of 113 academic studies published in the world 
between 1994 and 2020, organizational learning has a mediating role between the factors that facilitate information technologies and firm performance (Ekowati and Handriana, 2021).

The generation and transfer of knowledge in organizations are important in obtaining a competitive advantage. Competitive advantage is achieved by the internal transfer of knowledge and the prevention of its transfer to competitors. The transfer between people is easier than companies as people are more alike than companies. The inclusion of information into human interactions will positively affect internal transfer but hinder external transfer. In this respect, the basis of competitive advantage is the incorporation of knowledge in people, processes, and tasks (Argote and Ingram, 2000).

Benchmarking, one of the learning methods, is a widely accepted management tool for identifying and developing valuable marketing capabilities. According to the results of the study which is examining the benefits of comparing the marketing capabilities of high-performing firms to potential firm performance, benchmarking is a fundamental learning mechanism in defining, building, and developing the marketing capabilities of firms to achieve sustainable competitive advantage (Vorhies and Morgan, 2005).

Covering 700 firms in the UK manufacturing and service sectors, the study examines the relationship between benchmarking and organizational learning. The study shows that benchmarking contributes most to firm performance when it is used with organizational learning. Vision, training, problem-solving culture, and human resources strategy are essential components of benchmarking and organizational success. The presence of organizational learning in the firm is an indispensable element in the pursuit of superior performance (Pemberton et al., 2001).

\section{RESEARCH QUESTIONS}

This study aims to unearth how organizational learning impacts competitive advantage in terms of four subdimensions of organizational learning. As per the literature and the relationship among variables, we assume that organizational learning has a significant and positive impact on competitive advantage. Therefore, hypotheses are as follows:

$\mathrm{H}_{1}$ : Managerial commitment, one of the sub-dimensions of organizational learning, has a significant and positive effect on competitive advantage.

$\mathrm{H}_{2}$ : Systems perspective, one of the sub-dimensions of organizational learning, has a significant and positive effect on competitive advantage.

$\mathrm{H}_{3}$ : Openness and experimentation, one of the sub-dimensions of organizational learning, has a significant and positive effect on competitive advantage.

$\mathrm{H}_{4}$ : Knowledge transfer and integration, one of the sub-dimensions of organizational learning, has a significant and positive effect on competitive advantage.

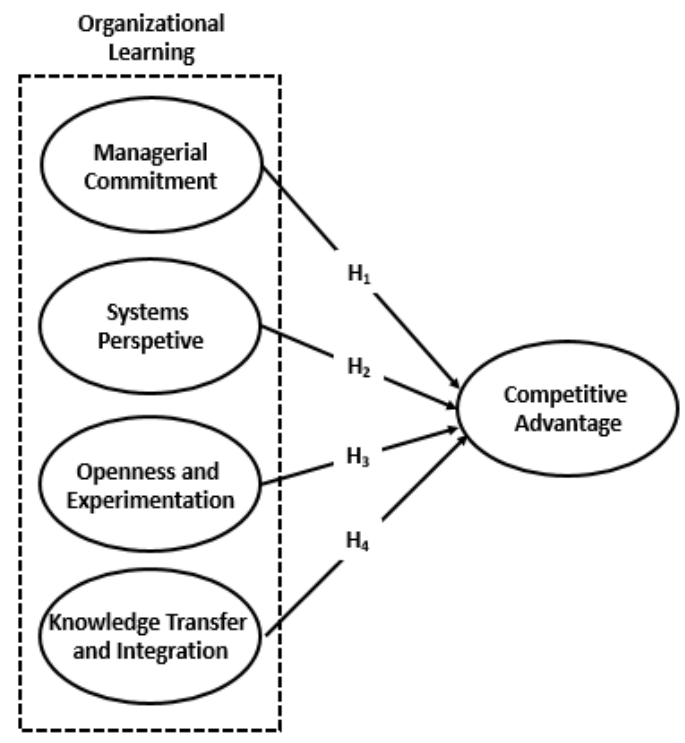

Figure 1. Research Model 


\section{PURPOSE OF THE STUDY}

Organizational learning is a complex phenomenon by its nature. In addition to theoretical studies and classifications on the concept, it is important to carry out empirical and quantitative studies in order to contribute to the field and reveal generalizable results. The purpose of this study is to analyze the effect of organizational learning on competitive advantage. The study is conducted in various sectors from Turkey without targeting any peculiar area. Since organizational learning and its effect on competitive advantage can be found in any industry, it is decided to include as many sectors as possible. Together with the studies conducted outside Turkey, the study will contribute to the literature by providing empirical results to come up with a generalizable conclusion. Consequently, it is aimed that the study will provide useful insights and knowledge to businesses in their strategic decisions and academia in their further research.

\section{RESEARCH METHODS}

The scope of the study is comprised of employees and executives from different sectors in Turkey. Since the observation unit of the research is based on individuals, data has been collected from employees and executives. The simple random sampling method was selected in the study due to time and cost constraints. The measurement method is based on quantitative analysis, data has been collected through an online survey and the participants were tried to be reached through the links of online forms. As a result, after the removal of inappropriate answers, 388 employees and managers from 319 different companies have participated in the survey.

As for the scales, their original language is English; hence, translation from the original language to Turkish and then reverse translation has been applied. Following receiving feedback from the subject matter experts and considering cultural context, the scales have been finalized. The latent constructs are analyzed by using a five-point Likert scale ranging from strongly disagree (1) to strongly agree (5).

In order to measure organizational learning, the scale developed by Jerez-Gomez et al (2005) has been used in the study. This scale is composed of managerial commitment, system perspective, openness and experimentation along with knowledge transfer and integration with 16 questions. In measuring subdimensions, there are five questions for managerial commitment, three questions for system perspective, four questions for openness and experimentation, and four questions for knowledge transfer and integration. For competitive advantage, the scale developed by Sigalas et al (2013) has been applied in the study. This is a scale consisting of four items with one dimension. Hence, it provides a lot of convenience for employees and executives to complete their contributions.

The job profiles of the participants were examined as demographic characteristics. From this point of view, the field of study consists of the total work experience, the total experience in the company, and the level of the position within the company. According to the descriptive statistics, $70.4 \%$ of the participants have a total work experience of up to 15 years. As for the seniority level in the company, approximately $79 \%$ of the participants have been working in the company for up to 10 years. Finally, when we look at the level of positions within the company, $22.7 \%$ of the participants are in the entry-level positions, $50.8 \%$ of them are mid-level management and $26.5 \%$ of the participants are senior management.

Before starting the analysis of the research model, the reliability and validity analysis of the research model is tested. In this context, internal consistency reliability, convergent validity, and discriminant validity are examined. As a result of the analysis, since the Cronbach alpha values of all factors are greater than 0.7 , it can be asserted that there is internal consistency reliability (Hair et al., 2014). To ensure convergent validity, factor loadings must be greater than 0.7, and the average variance extracted (AVE) value must be greater than 0.5 (Hair et al., 2014; Fornell and Larcker, 1981). It is seen that factor loadings are between 0.535 and 0.893 (Table 1). According to Hair et al. (2017), it is suggested that the items with factor loadings between 0.4 and 0.7 should be excluded from the measurement model if their AVE or composite reliability (CR) values are below the threshold. CR values should be greater than 0.7 to ensure composite reliability (Bagozzi and Yi, 1998). For the calculated AVE and CR values are above the threshold values, bt 3 and sp3 items with factor loadings less than 0.7 are not excluded from the model. As a result, convergent validity is demonstrated. 
Journal of Global Strategic Management | V. 15 | N. 1 | 2021-June | isma.info | 047-057 | DOI: 10.20460/JGSM.2021.298

Table 1. Measurement Model Estimates

\begin{tabular}{|c|c|c|c|c|c|}
\hline Variable & Item & Factor Loading & $\begin{array}{c}\text { Reliability (Cronbach } \\
\text { Alpha) }\end{array}$ & $\begin{array}{c}\text { Composite } \\
\text { Reliability (CR) }\end{array}$ & $\begin{array}{c}\text { Average } \\
\text { Variance } \\
\text { Extracted (AVE) }\end{array}$ \\
\hline \multirow{4}{*}{$\begin{array}{l}\text { Openness and } \\
\text { Experimentation }\end{array}$} & ad1 & 0.761 & \multirow{4}{*}{0.839} & \multirow{4}{*}{0.893} & \multirow{4}{*}{0.676} \\
\hline & $\operatorname{ad} 2$ & 0.805 & & & \\
\hline & $\mathrm{ad} 3$ & 0.863 & & & \\
\hline & ad4 & 0.856 & & & \\
\hline \multirow{4}{*}{$\begin{array}{l}\text { Knowledge } \\
\text { Transfer and } \\
\text { Integration }\end{array}$} & bt1 & 0.826 & \multirow{4}{*}{0.769} & \multirow{4}{*}{0.853} & \multirow{4}{*}{0.599} \\
\hline & bt2 & 0.830 & & & \\
\hline & bt3 & 0.553 & & & \\
\hline & bt4 & 0.847 & & & \\
\hline \multirow{3}{*}{$\begin{array}{l}\text { Systems } \\
\text { Perspective }\end{array}$} & sp1 & 0.893 & \multirow{3}{*}{0.701} & \multirow{3}{*}{0.828} & \multirow{3}{*}{0.628} \\
\hline & $\mathrm{sp} 2$ & 0.894 & & & \\
\hline & sp3 & 0.535 & & & \\
\hline \multirow{5}{*}{$\begin{array}{l}\text { Managerial } \\
\text { Commitment }\end{array}$} & $\mathrm{ib} 1$ & 0.840 & \multirow{5}{*}{0.895} & \multirow{5}{*}{0.923} & \multirow{5}{*}{0.705} \\
\hline & ib2 & 0.866 & & & \\
\hline & ib3 & 0.849 & & & \\
\hline & ib4 & 0.862 & & & \\
\hline & ib5 & 0.780 & & & \\
\hline \multirow{4}{*}{$\begin{array}{l}\text { Competitive } \\
\text { Advantage }\end{array}$} & re1 & 0.875 & \multirow{4}{*}{0.863} & \multirow{4}{*}{0.907} & \multirow{4}{*}{0.709} \\
\hline & re2 & 0.866 & & & \\
\hline & re3 & 0.794 & & & \\
\hline & re4 & 0.831 & & & \\
\hline
\end{tabular}

In order to determine the discriminant validity, the criteria proposed by Fornell and Larcker (1981) and the Heterotrait-Monotrait Ratio (HTMT) criteria proposed by Henseler, Ringle and Sarstedt (2015) must be sustained. The square root of the AVE values of the factors should be greater than the correlations between the factors in the research, according to Fornell and Larcker's (1981) criteria. The values in parentheses in Table 2 are the square root of AVE values. Since these values are higher than correlation values with other factors, Fornell and Larcker criteria is met.

Table 2. Convergent Validity Results (Fornell and Larcker Criteria)

\begin{tabular}{|c|l|c|c|c|c|c|}
\hline \multicolumn{2}{|c|}{ Factors } & $\mathbf{1}$ & $\mathbf{2}$ & $\mathbf{3}$ & $\mathbf{4}$ & $\mathbf{5}$ \\
\hline $\mathbf{1}$ & Openness and Experimentation & $(0.822)$ & & & & \\
\hline $\mathbf{2}$ & Knowledge Transfer and Integration & 0.478 & $(0.774)$ & & & \\
\hline $\mathbf{3}$ & Competitive Advantage & 0.434 & 0.384 & $(0.842)$ & & \\
\hline $\mathbf{4}$ & Systems Perspective & 0.419 & 0.432 & 0.432 & $(0.792)$ & \\
\hline $\mathbf{5}$ & Managerial Commitment & 0.501 & 0.430 & 0.443 & 0.498 & $(0.840)$ \\
\hline
\end{tabular}

HTMT criteria is defined as the ratio of the average of the correlations of all items in the study to geometric means of the correlations of variable items. Henseler et al (2015) assert that the HTMT value should be less than 0.9 while mentioning that HTMT value should be less than 0.85 for the variables that are far away from each other. As per Table 3, since all HTMT values are less than threshold values, it could be stated that discriminant validity is provided. 
Journal of Global Strategic Management | V. 15 | N. 1 | 2021-June | isma.info | 047-057 | DOI: 10.20460/JGSM.2021.298

Table 3. Convergent Validity Results (Henseler et al. Criteria)

\begin{tabular}{|l|l|l|l|l|l|l|}
\hline \multicolumn{2}{|c|}{ Factors } & $\mathbf{1}$ & $\mathbf{2}$ & $\mathbf{3}$ & $\mathbf{4}$ & $\mathbf{5}$ \\
\hline $\mathbf{1}$ & Openness and Experimentation & & & & & \\
\hline $\mathbf{2}$ & Knowledge Transfer and Integration & 0.573 & & & & \\
\hline $\mathbf{3}$ & Competitive Advantage & 0.503 & 0.463 & & & \\
\hline $\mathbf{4}$ & Systems Perspective & 0.518 & 0.544 & 0.522 & & \\
\hline $\mathbf{5}$ & Managerial Commitment & 0.574 & 0.505 & 0.497 & 0.594 & \\
\hline
\end{tabular}

The structural equation modeling to test the hypotheses developed for this study is demonstrated in Figure 2. For the structural equation modeling, the partial least squares (PLS-SEM) is applied in the research by using SmartPLS 3.2.9 statistical package. During the analysis, the PLS algorithm is used for path coefficients, $\mathrm{R}^{2}, \mathrm{f}^{2}$, and linearity while Blindfolding analysis is utilized for estimating power $\left(\mathrm{Q}^{2}\right)$. The research results can be found in Table 4 for these values.

Table 4. Research Model Coefficients

\begin{tabular}{|c|c|c|c|c|c|}
\hline & & VIF & $\mathbf{R}^{2}$ & $\mathbf{f}^{2}$ & $\mathbf{Q}^{2}$ \\
\hline Openness and Experimentation & \multirow{4}{*}{ Competitive Advantage } & 1.538 & \multirow{4}{*}{0.304} & 0.035 & \multirow{4}{*}{0.208} \\
\hline Knowledge Transfer and Integration & & 1.454 & & 0.014 & \\
\hline Managerial Commitment & & 1.583 & & 0.034 & \\
\hline Systems Perspective & & 1.472 & & 0.040 & \\
\hline
\end{tabular}

If we check for variance inflation factor (VIF) values in Table 4, these values are between 1.472 and 1.583 so that they are less than the threshold value of 5 . Hence, it can be stated that there is no collinearity issue among the variables (Hair et al., 2014). As for the $\mathrm{R}^{2}$ value of the model, the organizational learning subdimensions can explain $30.4 \%$ of the variance of the competitive advantage.

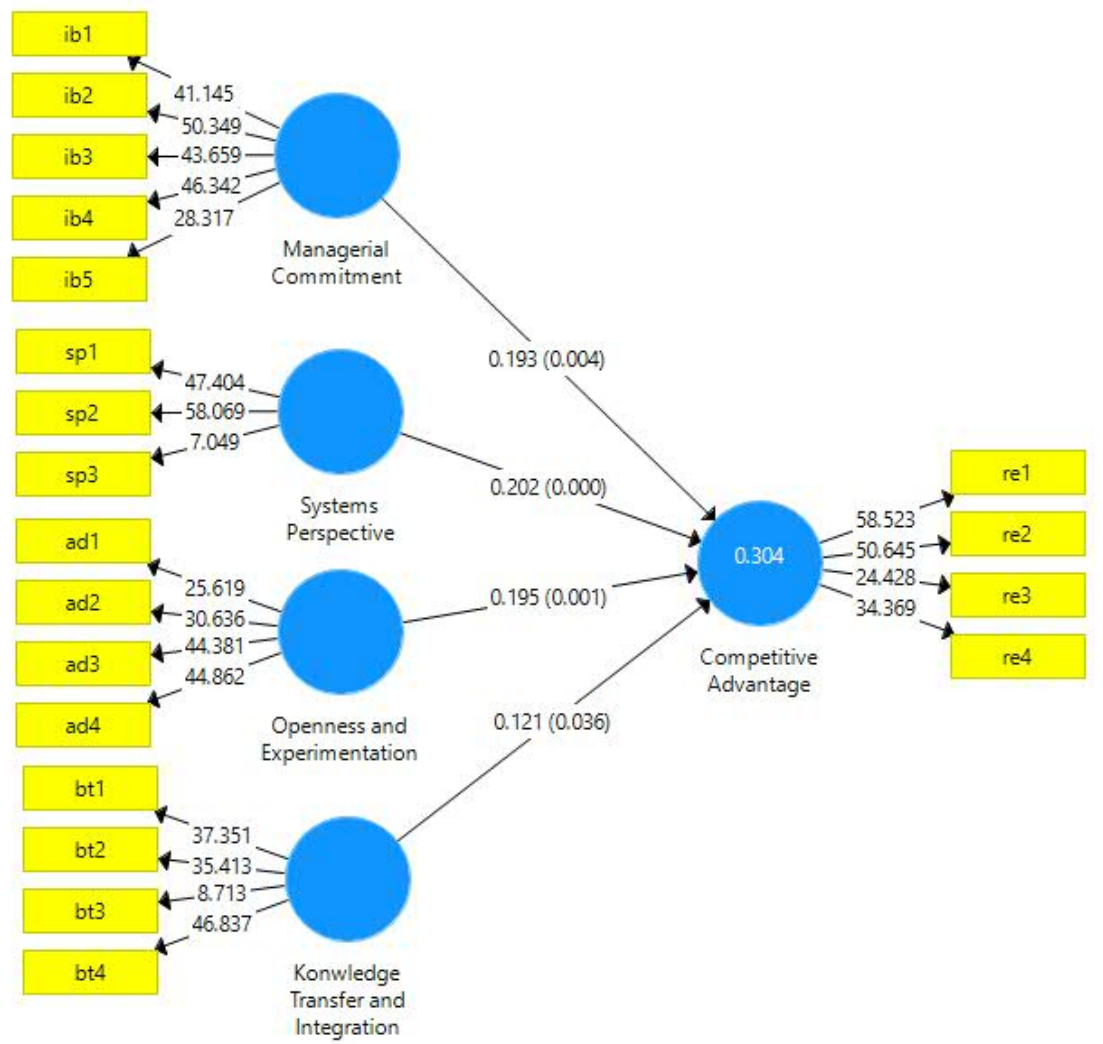

Figure 2. Structural Equation Model 
Another important aspect of Table 4 is related to the effect size coefficient $\left(\mathrm{f}^{2}\right)$. According to Cohen (1988), the effect size coefficient is low if it between 0.02 and 0.15 . It is considered as a medium if it is located between 0.15 and 0.35 while it is regarded as high for $\geq 0.35$. It is declared that there is no effect in case the value is less than 0.02 (Sarstedt, Ringle and Hair, 2017). Therefore, openness and experimentation $\left(\mathrm{f}^{2}=0.035\right)$, managerial commitment $\left(\mathrm{f}^{2}=0.034\right)$ and systems perspective $\left(\mathrm{f}^{2}=0.040\right)$ have low effect on the competitive advantage. However, knowledge transfer and integration $\left(\mathrm{f}^{2}=0.014\right)$ does not have any impact on the competitive advantage as per the effect size coefficient.

In order to state that the research model has an estimating power for the endogenous variables, calculated estimating power coefficients of the endogenous variables $\left(\mathrm{Q}^{2}\right)$ should be greater than zero (Hair et al., 2014). As the $Q^{2}$ value in Table 4 is 0.208 which is higher than zero, it could be asserted that the research model has the estimating power for the competitive advantage.

\section{FINDINGS}

Bootstrapping is used to evaluate the significance of path coefficients by taking 5,000 subsamples in order to estimate t-values. The analysis is conducted based on the $95 \%$ confidence level while the hypothesis testing and structural relationship could be seen in Table 5. According to the results, managerial commitment has a significant and positive effect $(\beta=0.193 ; \mathrm{p}=0.004<0.05)$ on competitive advantage; therefore, $\mathrm{H}_{1}$ is supported. The other supporting findings are t-value (2.881), greater than 1.96 , and the standardized beta value that lies on the confidence interval of 0.058 and 0.324 .

It has been found out that systems perspective positively and significantly $(\beta=0.202 ; p=0.000<0.05)$ affects competitive advantage and leading to support of $\mathrm{H}_{2}$. Since t-value is the highest (3.501) and p-value is the smallest (0.000) compared to other independent variables, it can be said that systems perspective have the strongest effect on competitive advantage. This finding is parallel with the effect size coefficient because systems perspective again has the largest $\mathrm{f}^{2}$ value concerning other sub-dimensions of organizational learning.

Similarly, $\mathrm{H}_{3}$ is supported since openness and experimentation has a significant and positive impact $(\beta=0.195 ; p<0.05)$ on competitive advantage. Openness and experimentation has the second strongest effect on competitive advantage since t-value (3.237), the standardized beta value (0.195), and the effect size coefficient $\left(\mathrm{f}^{2}=0.035\right)$ are similarly the second largest value among independent variables.

Lastly, even though the p-value of knowledge transfer and integration is 0.036 , it is still less than the 0.05 threshold value; hence this relationship is significant. Since the effect is also positive $(\beta=0.121), \mathrm{H}_{4}$ is also supported as one of the findings of this study. In parallel with the effect size coefficient finding $\left(\mathrm{f}^{2}=0.014\right)$, the effect of knowledge transfer and integration is the weakest one on competitive advantage. This finding can be supported with the lowest $t$-value (2.093) and the standardized beta value $(0.121)$ along with the highest p-value (0.036) concerning other factors.

\section{Table 5. Hypothesis Testing}

\begin{tabular}{|c|l|l|c|c|c|c|c|}
\hline $\begin{array}{c}\text { Hypo- } \\
\text { theses }\end{array}$ & Independent Variable & $\begin{array}{l}\text { Dependent } \\
\text { Variable }\end{array}$ & $\begin{array}{c}\text { Standar- } \\
\text { dized }\end{array}$ & $\begin{array}{c}\text { Standard } \\
\text { Deviation }\end{array}$ & t Value & p Value & $\begin{array}{c}\% 95 \\
\text { Confidence } \\
\text { Interval }\end{array}$ \\
\hline $\mathrm{H}_{1}$ & Managerial Commitment & $\begin{array}{l}\text { Competitive } \\
\text { Advantage }\end{array}$ & 0.193 & 0.067 & 2.881 & 0.004 & $0.058 ; 0.324$ \\
\hline $\mathrm{H}_{2}$ & Systems Perspective & $\begin{array}{l}\text { Competitive } \\
\text { Advantage }\end{array}$ & 0.202 & 0.058 & 3.501 & 0.000 & $0.086 ; 0.311$ \\
\hline $\mathrm{H}_{3}$ & $\begin{array}{l}\text { Openness } \\
\text { Experimentation }\end{array}$ & $\begin{array}{l}\text { Competitive } \\
\text { Advantage }\end{array}$ & 0.195 & 0.060 & 3.237 & 0.001 & $0.077 ; 0.314$ \\
\hline $\mathrm{H}_{4}$ & $\begin{array}{l}\text { Knowledge Transfer and } \\
\text { Integration }\end{array}$ & $\begin{array}{l}\text { Competitive } \\
\text { Advantage }\end{array}$ & 0.121 & 0.058 & 2.093 & 0.036 & $0.010 ; 0.235$ \\
\hline
\end{tabular}

\section{CONCLUSION}

As studies show, increasing competition makes the survival of companies even more difficult. Change is inevitable for companies due to the environment and they try to keep up with this change by learning. Companies that have adopted organizational learning develop themselves in every moment of competition and firstly survive with the advantage they have gained and then carry out successful results. According to 
the research model formed after the literature review, hypotheses were proposed and the research model was tested empirically with the survey.

According to the findings, organizational learning, whose sub-dimensions are managerial commitment, systems perspective, openness and experimentation along with knowledge transfer and integration, significantly and positively affects competitive advantage. The strongest effect among sub dimensions is with systems perspective and this is parallel with the ideas of Senge (1990) since he indicates that systems thinking is the most important aspects in terms of observing the whole system. Employees with a system perspective make a positive impact on the competition by making decisions not only for their departments but also for the benefit of the whole company, with a holistic point of view. Openness and experimentation has the second strongest effect on competitive advantage and this demonstrates that employees who learn by experimenting in an open environment make a more positive contribution to the company by innovative ideas. The openness could be linked with benchmarking which is fundamental learning mechanism outside company. Benchmarking affects competitive advantage (Vorhies and Morgan, 2005) and firm performance (Pemberton et al., 2001) and it can be implemented in an open system. And then, managerial commitment is also useful to gain competitive advantage and that could be explained by high job satisfaction and motivation. Thanks to managerial commitment, better performance of employees provides a competitive advantage. The weakest effect is with knowledge transfer and integration and it is almost above the threshold as per the empirical findings. According to the literature, inclusion of the information is going to increase competitive advantage (Argote and Ingram, 2000); therefore, this finding is compatible with theoretical background.

It has been supported by various studies in the literature that organizational learning affects competitive advantage. There are studies stating that organizational learning directly affects competitive advantage (Appelbaum and Gallagher, 2000; Hamama and Tayeb, 2020). These findings support the outputs of this study via different ways in different times. In addition to the direct effect, in other studies examining the mediation effect, there are also studies in the literature where organizational learning directly affects competitive advantage (Tu and $\mathrm{Wu}, 2021$; Dass and Chelliah, 2021) or indirectly (Camison and VillarLopez, 2011). As a result of them, the theoretical infrastructure is established and the results of this study support this infrastructure.

The study aims to contribute to the practical testing of the conceptual framework by applying them in various sectors of Turkey. It is one of the important results of the study that companies whose competitors are both from local and global will gain a competitive advantage if they invest in organizational learning due to the increasing pressure. It has been revealed that investments made towards the four sub-dimensions discussed in the study will bring positive results related to the competitive advantage.

First of all, it is the system perspective that has the strongest impact in the study, and it can be said that the managers' bringing a holistic system perspective to their employees is the first investment for their companies to be made in order to gain competitive advantage. Employees will provide high added value if they act with the whole company in their minds. Since the secondary effect comes from openness and experimentation, it can be said that participation with democratic management is important in terms of providing an opportunity for employees to influence. An employee who can get ideas from outside, apply them without hesitation and who is given responsibility will naturally take his company one step ahead of the competition. It is seen that ensuring managerial commitment is an area that can be invested for companies considering to gain competitive advantage. The fact that knowledge transfer and integration has the least impact shows that it is a better option for companies to internalize the knowledge by producing it internally, rather than taking the knowledge from outside and then disseminating.

Future work may be done with different variables and structures. In addition, the effects of mediator and moderator variables in these new structures will also contribute to the literature and business life. Although a single-term analysis is made in this study, conducting longitudinal analysis in order to come up with more generalizations can be done regarding the results. 


\section{REFERENCES}

Appelbaum, S. H. and Gallagher, J., (2000), The competitive advantage of organizational learning, Journal of Workplace Learning, 12(2), pp.40-56.

Argote, L. and Ingram, P., (2000), Knowledge transfer: A basis for competitive advantage in firms, Organizational Behavior and Human Decision Processes, 82(1), pp.150-169.

Argyris, C. and Schön, D., (1978), Organizational Learning, Addison-Wesley, Reading, MA.

Bagozzi, R. P. and Yi, Y., (1988), On the evaluation of structural equation models, Journal of the Academy of Marketing Science, 16(1), pp.74-94.

Barney, J., (1991), Firm resources and sustained competitive advantage, Journal of Management, 17(1), pp.99-120.

Barney, J. and Hesterly, W. S., (2010), Strategic management and competitive advantage: Concepts and cases, Prentice Hall, New Jersey.

Camison, C. and Villar-Lopez, A., (2011), Non-technical innovation: Organizational memory and learning capabilities as antecedent factors with effects on sustained competitive advantage, Industrial Marketing Management, 40(8), pp.1294-1304.

Cohen, J., (1988), Statistical power analysis for the behavioral sciences, Lawrence Erlbaum Associates, New Jersey.

Daft, R. L. and Weick, K. E., (1984), Toward a model of organizations as interpretation systems, Academy of Management Review, 9(2), pp.284-295.

Dass, P. S. and Chelliah, S., (2021), Organizational Learning, Collective Human Capital and Performance of MNEs: The Mediating Effect of Competitive Advantage, Asian Journal of Research in Business and Management, 3(1), pp.80-95.

Ekowati, D. and Handriana, T., (2021), A Systematic Literature Review: The Influence of Information Technology Enabler And Organizational Learning on Performance, Library Philosophy and Practice, pp.1-21.

Eren, E., (2013), Stratejik Yönetim ve İşletme Politikası, Beta Yayınevi, İstanbul.

Fiol, C. M and Lyles, M. A., (1985), Organizational learning, Academy of Management Review, 10(4), pp.803-813.

Fornell, C. and Larcker, D.F., (1981), Evaluating structural equation models with unobservable variables and measurement error, Journal of Marketing Research, 18(1), pp.39-50.

Grant R. M., (1996), Prospering in dynamically-competitive environments: organizational capability as knowledge integration, Organization Science, 7(4), pp.375 -387.

Grant, R. M., (2008), Contemporary Strategy Analysis, Blackwell Publishing, Oxford.

Hair, J. F., Black, W. C., Babin, B. J. \& Anderson, R. E., (2014), Multivariate data analysis, Pearson Education Limited, Essex.

Hair, J. F., Hult, G. T. M., Ringle, C. M. \& Sarstedt, M., (2017), A Primer on Partial Least Squares Structural Equation Modeling (PLS_SEM), Sage Publications, Thousand Oaks.

Hamama, M. and Tayeb, B., (2020), The impact of organizational learning on competitive advantage Case Study of "Algerie Telecom" of Laghouat, Dirassat Journal Economic Issue, 11(1), pp.507-520.

Hamel, G. and Prahalad, C. K., (1990), The core competence of the corporation, Harvard Business Review, 68(3), pp.79-91.

Hedberg, B., (1981), How organizations learn and unlearn, Handbook of organizational design, (1), pp.327. 
Henseler, J., Ringle, C. M. \& Sarstedt, M., (2015), A new criterion for assessing discriminant validity in variance-based structural equation modeling, Journal of the Academy of Marketing Science, 43(1), pp.115-135.

Innosight, (11/07/2021), 2021 Corporate Longevity Forecast, Retrieved from https://www.innosight.com/insight/creative-destruction/.

Jerez-Gomez, P., Céspedes-Lorente, J. \& Valle-Cabrera, R., (2005), Organizational learning capability: a proposal of measurement, Journal of Business Research, 58(6), pp.715-725.

Kim, D. H., (1993), The link between individual and organizational learning, Sloan Management Review, 35(1), pp.37-50.

Krugman, P., (1994), Competitiveness: a dangerous obsession, Foreign Affairs, 73(2), pp.28-44.

Lim, N., (2010), Social loss aversion and optimal contest design, Journal of Marketing Research, 47(4), pp.777-787.

Lopez, S. P., Peon, J. M. M. \& Ordas, C. J. V., (2005), Organizational learning as a determining factor in business performance, The Learning Organization, 12(3), pp.227-245.

Lynch, R. L., (2000), Corporate Strategy, Prentice Hall, Essex.

March, J. G. and Olsen, J. P., (1975), The uncertainty of the past: Organizational learning under ambiguity, European Journal of Political Research, 3(2), pp.147-171.

Nonaka, I. and Takeuchi, H., (1995), The knowledge-creating company: How Japanese companies create the dynamics of innovation, Oxford University Press, Oxford.

Pemberton, J. D., Stonehouse, G. H. \& Yarrow, D. J., (2001), Benchmarking and the role of organizational learning in developing competitive advantage, Knowledge and Process Management, 8(2), pp.123-135.

Porter, M. E., (1985), Competitive Advantage: Creating and Sustaining Superior Performance, Free Press, New York.

Porter, M. E., (1990), The competitive advantage of nations, Harvard Business Review, 68(2), pp.73-93.

Porter, M. E., (2015), Rekabet Stratejisi: Sektör ve Rakip Analizi Teknikleri, Aura Kitapları, İstanbul.

Sarstedt, M., Ringle, C. M. \& Hair, J. F., (2017), Partial Least Squares Structural Equation Modelling, Handbook of Market Research, 26(1), pp.1-40.

Senge, P., (1990), The Fifth Discipline: The Art and Practice of the Learning Organization, Currency Doubleday, New York.

Sigalas, C., Economou, V. P. \& Georgopoulos, N. B., (2013), Developing a measure of competitive advantage, Journal of Strategy and Management, 6(4), pp.320-342.

Simon, H. A., (1991), Bounded rationality and organizational learning, Organization Science, 2(1), pp.125-134.

Tu, Y. and Wu, W., (2021), How does green innovation improve enterprises' competitive advantage? The role of organizational learning, Sustainable Production and Consumption, 26(1), pp.504-516.

Vorhies, D. W. and Morgan, N. A., (2005), Benchmarking marketing capabilities for sustainable competitive advantage, Journal of Marketing, 69(1), pp.80-94.

Williams, A. P., (2001), A belief-focused process model of organizational learning, Journal of management studies, 38(1), pp.67-85. 